\title{
Recent dating of extinct Atlantic gray whale fossils, (Eschrichtius robustus), Georgia Bight and Florida, western Atlantic Ocean
}

\author{
Ervan G Garrison ${ }^{\text {Corresp.. }}{ }^{1}$, Gary S. Morgan ${ }^{2}$, Krista McGrath ${ }^{3}$, Camilla Speller ${ }^{\text {Corresp., }}{ }^{3,4}$, Alexander Cherkinsky ${ }^{5}$ \\ ${ }^{1}$ Geology, University of Georgia, Athens, GA, USA \\ 2 New Mexico Museum of Natural History \& Science, Albuquerque, NM, USA \\ 3 University of York, BioArch Centre, York, UK \\ 4 Department of Anthropology, University of British Columbia, Vancouver, British Columbia, Canada \\ ${ }^{5}$ Center for Applied Isotope Studies, University of Georgia, Athens, GA, United States \\ Corresponding Authors: Ervan G Garrison, Camilla Speller \\ Email address: egarriso@uga.edu, speller@palaeome.org \\ The Atlantic gray whale (Eschrichtius robustus) presents an interesting case study of \\ climate related dispersal and extinction. While (limited) fossil records confirm its presence \\ in the Atlantic up until the $18^{\text {th }}$ Century, its abundance and distribution within the Eastern \\ and Western basins are still not well understood. The discovery of presumed gray whale \\ fossil remains from the Georgia Bight and the Atlantic coast of Florida, from the mid-1980s \\ to late-2000s, provide a new opportunity to recover additional data regarding their \\ chronology within the Western basin. Here we apply AMS (accelerator mass spectrometry) \\ radiocarbon technique to eight fossil whale finds, identifying dates within Marine Isotope \\ Stage (MIS) 3 (59-24 ka) and the late Holocene, 2,000 yr BP. We additionally confirm the \\ taxonomic identification of two fossil bone samples as $E$. robustus using collagen peptide \\ mass fingerprinting (ZooMS). The obtained dates, when combined with a larger corpus of \\ previously published Atlantic gray whale fossil dates, support the hypothesis for the \\ decline of the Atlantic gray whale in the late Pleistocene and the late Holocene. These new \\ data augment the findings of the Eastern Atlantic Basin and better incorporate the \\ Western Atlantic Basin into a pan-ocean understanding for the species.
}


1 Recent dating of extinct Atlantic gray whale fossils (Eschrichtius robustus), Georgia Bight and Florida, 2 western Atlantic Ocean

3

ERVAN G. GARRISON, ${ }^{1}$ Geology, the University of Georgia, Athens, GA 30602, USA;

GARY S. MORGAN, New Mexico Museum of Natural History \& Science, Albuquerque, New Mexico, USA; KRISTA MCGRATH, BioArCh Centre, University of York, York YO10 5DD, United Kingdom; CAMILLA SPELLER, BioArCh Centre, University of York, York YO10 5DD, United Kingdom and Department of Anthropology, University of British Columbia, Vancouver, BC, V6T 1Z1. ALEXANDER CHERKINSKY, Center for Applied Isotope Studies, the University of Georgia, Athens, GA 30602, USA

\section{ABSTRACT}

The Atlantic gray whale (Eschrichtius robustus) presents an interesting case study of climate related dispersal and extinction. While (limited) fossil records confirm its presence in the Atlantic up until the $18^{\text {th }}$ Century, its abundance and distribution within the Eastern and Western basins are still not well understood. The discovery of presumed gray whale fossil remains from the Georgia Bight and the Atlantic coast of Florida, from the mid-1980s to late-2000s, provide a new opportunity to recover additional data regarding their chronology within the Western basin. Here we apply AMS (accelerator mass spectrometry) radiocarbon technique to six fossil whale finds, identifying dates within Marine Isotope Stage (MIS) 3 (59-24 ka) and the late Holocene, 2,000 yr BP. We additionally confirm the taxonomic identification of two fossil craniae as E. robustus using collagen peptide mass fingerprinting (ZooMS). The obtained dates, when combined with a larger corpus of previously published Atlantic gray whale fossil dates, support the hypothesis for the decline of the Atlantic gray whale in the late Pleistocene and the late Holocene. These new data augment the findings of the Eastern Atlantic Basin and better incorporate the Western Atlantic Basin into a pan-ocean understanding for the species.

Key words: gray whale, western Atlantic basin, paleontology, stable isotopes, radiocarbon dating, protein studies. 
$31{ }^{1}$ Corresponding author (e-mail: egarriso@uga.edu).

\section{Introduction}

Recent studies have suggested that changes in species distribution during the Late Pleistocene-

Early Holocene transition were caused both by habitat tracking as well as by extirpation of populations outside of isolated habitat refugia (Dalén et al. 2007, de Bruyn et al. 2011, Hofreiter et al. 2004, Hofreiter 2008, Hofreiter and Stewart 2009; Stewart, 2009). The gray whale (Eschrichtius robustus) presents an interesting case study by which to study this type of climate-related dispersal and extinction. Based on fossil evidence, the gray whale was present in both the North Pacific and North Atlantic during the Late Pleistocene and early Holocene, and migration from the Pacific to the Atlantic is thought to have been strongly shaped by Pleistocene climate shifts affecting potential dispersal routes and benthic feeding habitats. Both fossil and historical accounts suggest that the Atlantic gray whale was extinct in the North Atlantic by the mid-1700's (Mead and Mitchell 1984; Lindquist 2000), with both climate and anthropogenic factors implicated in its demise. Nevertheless, due to a paucity of fossil data in both the Eastern and Western basins, the diachronic distribution and abundance of gray whales prior to their disappearance is not well understood. Mysticeti. Taxonomically, the phylogenetic placement of Eschrichtiidae has been controversial, with several suggested topologies (i.e., McLeod et al. 1993; Arnason et al. 1992, 1993; Arnason and Gullberg 1994, 1996; Sasaki et al. 2005). Ironically, the extant gray whale Eschrichtius robustus was originally described (as Balaenoptera robusta) based on a Holocene fossil skeleton from Gräsö, Sweden (Lilljeborg, 
51 1861; English translation in Lilljeborg, 1867). E. robustus was discovered as a living animal in the Pacific

52 shortly thereafter. The family Eschrichtiidae includes only one the living genus and species, Eschrichtius

53 robustus but modern workers describe four putative genera of Eschrichtiidae: Eschrichtius,

Archaeschrichtius, Eschrichtioides and Gricetoides ( Bisconti,2008; Deméré et al, 2008; Icshishima, et al,

2006 and Steeman 2007. As the North Atlantic gray whale population went extinct prior to formal

analysis of its taxonomy (Barnes and McLeod 1984; Lindquist 2001), it was not clear if the Atlantic and

Pacific populations represented distinct species. Nor is it clear what drove the extirpation of this species

in the North Atlantic. Lindquist (2001)is by far the most authoritative review of this question particularly

with regard to any anthropogenic causation - prehistoric and historic -such as whaling, either

opportunistic procurement or systematic hunting. It is noteworthy that two separate archaeological

studies using DNA and collagen peptide mass fingerprinting (ZooMS) methods, respectively found no

evidence of gray whale in historic whaling assemblages in the western North Atlantic (McLeod et al.

2010) or eastern North Atlantic (Buckley et al. 2014). Recent genetic comparisons of North Atlantic

fossil material and extant North Pacific populations by Alter et al. (2015), however, confirmed that they

represent the same species, connected through intermittent inter-ocean exchange or dispersals from

the Pacific during openings of the Bering Strait (Alter et al. 2015). Moreover, combined radiocarbon

dating and genetic results led Alter et al. to conclude that "dispersal between the Pacific and Atlantic

was climate-dependent, and occurred - at least twice - both during the Pleistocene prior to the last

glacial period, and the early Holocene immediately following the opening of the Bering Strait."

In the Eastern Atlantic Basin, Pleistocene marine mammal taxa are known from the southern

part of the North Sea and the Eurogeul - recovered during the recent channel deepening project of the

belong to a cold Late Pleistocene fauna (Mol et al. 2006), and confirm with certainty the Late

Pleistocene as well as the Holocene occurrence of gray whales in the eastern Atlantic Ocean. In 
contrast, only a dozen fossils have been recovered from the Western Basin of the Atlantic, with the majority of dated remains corresponding to Holocene (Mead and Mitchell 1984; Bryant, 1995). Only one study to date has recorded a late Pleistocene presence in this region (Noakes et al. 2013), raising questions about the extent to which the Western Basin was frequented by gray whales prior to the Holocene, and the genetic relationship between Western and Eastern populations of Atlantic gray whale. To date, relatively few archaeological or paleontological gray whale specimens have been identified on the Eastern seaboard of North America, and ancient DNA (aDNA) surveys of historic whaling assemblages in this region have failed to detect any additional gray whale specimens (Rastogi et al. 2004; McLeod et al. 2008). This overall paucity of fossil and genetic data makes it difficult to draw meaningful conclusions about the abundance, distribution, and chronology of Atlantic gray whales in the Western Basin during both the Pleistocene and Holocene.

Here we apply AMS dating to five new fossil gray whale finds from Florida and Georgia, and confirm taxonomic identifications of two craniae using collagen peptide mass fingerprinting. Our results provide new evidence for the Late Pleistocene presence of gray whale in the Western basin, and combined with other fossil dates for the Atlantic, support the decline of Atlantic gray whales in the Pleistocene prior to post-glacial re-population.

\section{Methods}

In our study, we analyzed six-fossil gray whale specimens from the western Atlantic Ocean. We newly applied AMS dating to three of the finds and collated with ages of previously published specimens (Garrison et. 2012b). Collagen peptide mass fingerprinting (ZooMS) was performed to confirm taxonomic identifications based on standard morphological comparisons. Two skulls were found on Florida beaches (Fig. 1),-one dentary, and three puted dentary fragments were recovered from an 
97

underwater site, offshore Georgia (Noakes et al. 2009; Garrison, et al. 2012b; Noakes et al. 2013) (Figs. $1,2,3)$.

9

cataloged in the paleontology collection of the Georgia Museum of Natural History (GMNH), University of Georgia, Athens. The fossils from the Hobe Sound and Jacksonville Beach localities in Florida are cataloged in the vertebrate paleontology collection of the Florida Museum of Natural History, University of Florida (specimen acronym UF), Gainesville.

Figure 1. The Georgia Bight and Florida Peninsula, showing the location of the gray whale specimens discussed in the text. These records include specimens from the JY Reef and Gray's Reef National Marine Sanctuary in the Georgia Bight and Jacksonville Beach and Hobe Sound on the Atlantic Coast of Florida.

Figure 3. Two partial Holocene skulls gray whales (Eschrichtius robustus) from Florida (USA). Top row (A-

Figure 2. The late Pleistocene and Holocene specimens of the gray whale (Eschrichtius robustus), Research Ledge site, JY Reef, Georgia Bight used in this study. A: Lateral views of three dentary fragments (GMNH accession numbers, 00-28-09, 00-28-10, 00-28-13), B: Medial view of left dentary, (GMNH 4281) with comparison to North Sea specimen (top), Rotterdam Museum of Natural History collections, (NMR999100001783), scale is $20 \mathrm{~cm}$. Measurements of these specimens are in Table 1. C), Jacksonville Beach (UF 99000), A. posterior view, B. right lateral view, C. ventral view; Middle row (DF) Hobe Sound National Wildlife Refuge (NWR) (UF 69000), D. posterior, E. right lateral and F. ventral views); Bottom row, two views - medial and lateral - of the left periotic (internal ear bone) from the Hobe Sound skull. Both braincases are relatively intact from the condyles to the broken frontals. All Scale bars are $10 \mathrm{~cm}$; overall dimensions in Table 1. 
133

134

135

136

137

138

139

140

141

142

143

144

145

146

147

148

149

150

151

152

153

154

155

156

157

158

159

160

161

\section{Fossil localities of the Georgia and Florida gray whales}

The Georgia locality is J-Reef a low exposure of shell beds about 16 km north of the Gray's Reef (fig. 1).

At J-Reef the shell beds are in a conformable relationship with finer grained

sediment that dates to no earlier than the late Pleistocene (Garrison, et al, 2012).

The four dentary (?) fragments shown in figure 2 were recovered from the fine sediment or adjacent to the same outcrop on the sea floor. During subsequent dives, in fall 2006, the large fossil dentary was discovered partially embedded in the coquina (fig. 2 b). This coquina sand, typically deposited on a beach or in a nearshore marine environment, was probably the original sediment, like that of the Hobe Sound skull, in which it was preserved before being exposed.

The following details on the discovery and exact location of the gray whale skull from Hobe Sound (Fig. 3, Specimen UF 69000) were provided by Burkett S. Neely, Jr. (in litt., 6 June 1983) of the U. S. Fish and Wildlife Service (USFWS). The skull was discovered by a Mr. and Mrs. Kornit on 19 January 1983 at the edge of the surf on the northern end of Jupiter Island about $10 \mathrm{~km}$ south of St. Lucie Inlet, on the Hobe Sound National Wildlife Refuge (NWR), Martin County, southeastern Atlantic Coast of Florida (fig. 1). Exact coordinates for the Hobe Sound skull are $27^{\circ} 07^{\prime} 40^{\prime \prime}$ North latitude and $80^{\circ} 08^{\prime} 45^{\prime \prime}$ West longitude. The skull was collected later that same day by USFWS personnel. The discovery of the Hobe Sound skull apparently coincided with extensive beach erosion that occurred during a strong winter storm. Through the generosity of Burkett S. Neely, Jr. and the USFWS, the Hobe Sound gray whale skull was placed on permanent loan in the vertebrate paleontology collection of the Florida Museum of Natural History (FLMNH), University of Florida (UF), Gainesville (catalogue number UF 
162

163

164

69000). Mead and Mitchell (1984, p. 48) stated that "The specimen consists of most of the cranium of what looks like an adult..." However, upon closer examination, this skull consists only of a braincase, including both periotics (Fig. 3), and is from a very young individual or calf probably less than a year old. Robert K. Bonde (in litt, 19 July 1983), likewise, estimated that this specimen was from a very young calf, probably less than three months old. The Hobe Sound skull represents the southernmost record of $E$. robustus in the Atlantic Ocean, based on distributional maps in Mead and Mitchell (1984). Attached to the internal portion of the periotic (Fig. 3) of this juvenile skull is a small sample of sediment, consisting of medium to coarse quartz sand and fragments of mollusk shells, forming a semi-indurated "coquina." This coquina sand, possibly deposited on a beach or in a nearshore marine environment, was probably the original sediment in which the skull was preserved before being dislodged and washed up on the beach.

(1)

The second gray whale skull from Florida (FLMNH Specimen UF99000) was collected during the 1970s by Jesse S. Robertson of Jacksonville University on the beach at Jacksonville Beach, Duval County, northeastern Florida (approximate coordinates, $30^{\circ} 17^{\prime} \mathrm{N}, 81^{\circ} 23^{\prime} \mathrm{W}$ ) (figs. 1). Although the collector was unable to remember the specific details surrounding the discovery of this fossil, he did recollect it was found after a strong storm. The Jacksonville Beach gray whale skull consists of a braincase of a juvenile, compared to that of the younger calf from Hobe Sound.

\section{Carbon isotope analysis and AMS dating}

For the stable isotope analysis of samples we used both a Finnigan MAT 252 mass spectrometer, which is a dual-inlet mass spectrometer as well as a National Electrostatics Corporation Model 1.5SDH-1 
190

191

192

Pelletron 500 kV compact Accelerator Mass Spectrometer AMS) unit for precise analyses of carbon isotopes ${ }^{12} \mathrm{C},{ }^{13} \mathrm{C}$ and ${ }^{14} \mathrm{C}$. The Finnigan spectrometer is a double collector gas source mass spectrometer and allows for the measurement of two isotopes of oxygen and three isotopes of carbon with the double collector. It measures the ratio on the sample and the standard by alternating dual inlets. By contrast the Model 1.5SDH-1 Pelletron $500 \mathrm{kV}$ only analyzed for the three isotopes of carbon using Faraday cup collectors at the end of the beam line array.

\section{so we applied the bioapatite fraction dating technique (Cherkinsky 2009). Specimens were chemically} pretreated to remove all secondary carbonate and organics, but leave bioapatite in the bone structure. Bioapatite belongs to the group of hexagonal calcium phosphates, of which hydroxyapatite, $\left(\mathrm{Ca}_{10}\left(\mathrm{PO}_{4}\right)_{6}(\mathrm{OH})_{2}\right.$, is closest in structure to biological apatite. It differs from geological apatite by a high degree of isomorphic substitutions and absorption of carbonate and small crystal size, properties that each result in a poorer crystallization of bone bioapatite (LeGeros, 1984).

The carbonate substituted within bioapatite maintains its carbon isotope signature in both stable and radioactive isotopes. Carbonate occurs in several locations in the crystals, as absorbed ions on the surface and within the crystals. Substitutions are mainly in the phosphate position and most likely in the hydroxyl position. The absorbed carbonates are more labile but substituted ones are much more stable (they are actually structure carbonates) and contribute to saving original isotope composition. Thus, they could be used for radiocarbon dating.

The specimens were treated with a weak acetic acid $\left(\mathrm{CH}_{3} \mathrm{COOH}\right)$ bath under vacuum. Once washed and dried the samples were treated with phosphoric acid $\left(\mathrm{H}_{3} \mathrm{PO}_{4}\right)$ in reaction tubes and heated to ensure removal of all carbonates. The bone samples generated $\mathrm{CO}_{2}$ in the vacuum system and this gas was then 
213 analyzed in the mass spectrometer against a Vienna Pee Dee Belemnite standard (VPDB) with the per

214 mil [\%o] values of $\delta^{13} \mathrm{C}$ reported against VPDB and $\delta^{18} \mathrm{O}$ reported against VPDB and VSMOW.

215 We have used the internal standards which are:

216

217

218

219

220

221

222

223

224

225

226

227

228

229

230

231

232

233

234

235

236 $\delta 13 C, \%$ o $\delta 180, \%$

Fisher $\quad-0.64 \quad-14.90$

A $1296+2.56 \quad-0.60$

These standards were calibrated with National bureau of Standards (now NIST) NBS 19

$\delta 13 C, \%=+1.95$ and $\delta 180, \%=+28.60$.

For accelerator mass spectrometer isotopic analyses carbon dioxide was cryogenically purified

from the other reaction products and catalytically converted to graphite using the method of Vogel et al.

(1984). Graphite ${ }^{14} \mathrm{C} /{ }^{13} \mathrm{C}$ ratios were measured by the Model $1.5 \mathrm{SDH}-1$ Pelletron $0.5 \mathrm{MeV}$ accelerator

mass spectrometer. The sample ratios were compared to the ratio measured from the Oxalic Acid I (NBS

SRM 4990). The sample ${ }^{13} \mathrm{C} /{ }^{12} \mathrm{C}$ ratios were measured separately using a stable isotope ratio mass

spectrometer and expressed as $\delta^{13} \mathrm{C}$ with respect to VPDB, with an error of less than $0.1 \%$ o

\section{Collagen peptide mass fingerprinting}

We attempted to taxonomically identify five specimens using peptide mass fingerprinting: the three dentary fragments from JY Reef, Georgia Bight (GMNH 00-28-09, 00-28-10, 00-28-13 and the two Florida skull specimens (UF 69000, UF 99000). Collagen peptide mass fingerprinting (PMF), also known as ZooMS, is a rapid and cost-effective technique, whereby taxonomic groups are discriminated based on difference in the collagen protein sequence. Robust species identification can be accomplished by comparing collagen peptide fingerprints with the fingerprints from known samples using mass 
237 spectrometry (Collins et al. 2010). The success of this method has already been demonstrated for

238 ancient North Atlantic cetacean species, including Atlantic gray whale (Kirby et al. 2013; Buckley et al.

239 2014).

240 Sample preparation, mass spectrometry and data analysis followed that described in Buckley et

241 al (2014) and Evans et al. (2015) at the BioArCh centre, University of York. Briefly, between 10-30 mg of

242 bone powder was fully demineralized through immersion in $0.6 \mathrm{M}$ hydrochloric acid, followed by

243 gelatinization in $100 \mu \mathrm{l}$ of $50 \mathrm{mMol}$ ammonium bicarbonate at $65^{\circ} \mathrm{C}$ for 1 hour. The resulting collagen

244 was incubated with $0.4 \mu \mathrm{g}$ of trypsin overnight at $37^{\circ} \mathrm{C}$, acidified to $0.1 \%$ trifluoroacetic acid and purified

245 using a $100 \mu \mathrm{l} \mathrm{C18}$ resin ZipTip ${ }^{\circledR}$ pipette tip (EMD Millipore). The collagen extract was spotted in

246 triplicate on a 384 spot MALDI target plate, with calibration standards and run on a Bruker ultraflex III

247 MALDI TOF/TOF mass spectrometer. mMass software (Strohalm et al., 2008) was used to average

248 spectra replicates from each specimen, and compare to the list of $\mathrm{m} / \mathrm{z}$ markers for marine mammals

249 presented in Kirby et al. 2013 and Buckley et al. 2014.

250

251

\section{3. Results}

253

254 255

256

257

258 
260

261

262

263

264

265

266

267

268

269

270

271

272

273

274

275

276

277

278

279

280

281

282

283

Class MAMMALIA Linneaus, 1758

Order CETACEA Brisson, 1762

Suborder MYSTICETI Gray, 1864

Family ESCHRICHTIIDAE Ellerman and Morrison-Scott, 1951

Genus ESCHRICHTIUS Gray, 1864

ESCHRICHTIUS ROBUSTUS.

Eschrichtius cf. E. robustus (Lilljeborg, 1867).

Table 1. Cranial measurements (in $\mathrm{cm}$ ) of Quaternary gray whale (Eschrichtius robustus) skulls from Florida (this study).

284 skulls of Eschrichtius robustus (True 1983; 1904; Barnes and McLeod 1984) and a late Pliocene skull from 
285

286

287

288

290

291

292

293

294

295

296

297

298

299

300

301

302

303

304

305

306

307

308

\section{6}

Japan referred to Eschrichtius sp. (Ichishima et al., 2006). Because both Florida skulls consist only of the braincase, our comparisons are limited to characters present in posterior portion of the skull (Fig. 3;

Table 1), as well as several characters of the periotics (see next paragraph). Characters the Florida skulls share with E. robustus include: triangular-shaped occipital shield with prominent paired occipital tuberosities (see Fig. 3A, UF 99000); large occipital condyles; concave exoccipitals lateral to occipital condyles; large and posteriorly oriented paroccipital processes; short, massive postglenoid processes of the squamosals that are parabolic in shape; and presence of a squamosal cleft.

2

Figures $3 \mathrm{G}$ and $3 \mathrm{H}$ are external (= medial = tympanic) and internal (= lateral = cerebral) views,

respectively, of the left periotic from the juvenile gray whale skull from Hobe Sound, Florida (UF 69000).

The right periotic of this specimen is still preserved intact in the skull (Fig. 3F). The posterior process of the right periotic (= posterior petrotympanic process of Ichishima et al., 2006) is still attached to the skull in the second Florida fossil, from Jacksonville Beach (UF 99000; Fig. 3C). The periotics from the Hobe Sound skull are very similar to periotics from modern skulls of Eschrichtius robustus and to the periotic of a Pliocene skull of Eschrichtius from Japan (Ichishima et al., 2006). Specifically, the periotic of UF 69000 is similar to that of $E$. robustus in the short, triangular-shaped anterior process, comparatively large cochlear portion (as large as the body and anterior process of the periotic but excluding the posterior process), relatively fibrous posterior process, and the confluence of the fenestra cochleae and the aperture for the cochlear aqueduct. The anterior process of the perotic is proportionally small relative to the cochlear portion (pars cochlearis) in the fossil and Eschrichtius, compared to balaenopterids in which the anterior process is much larger. 
309 immature individuals based on the unfused basioccipital/basisphenoid joint or suture. Walsh and Berta

310 (2011) examined the closure of the bones in the occipital region in 20 skulls of E. robustus, including 18

311 calves under one year of age. They found that the basioccipital/basisphenoid joint becomes completely

312 ossified between 7 months and 1 year of age. The cranial measurements (Table 1), together with the

313 unfused basioccipital/basisphenoid joint, indicate that the Hobe Sound skull (UF 69000) is most likely a

314 newborn calf, whereas the somewhat larger Jacksonville Beach skull (UF 99000) was probably between

315 seven months and a year old. Both Holocene skulls of gray whales from Florida are juveniles less than a

316 year of age, lending credence to our suggestion that the east coast of Florida may have been a breeding

317 ground for the western Atlantic population of $E$. robustus (see below under Discussion).

Comparisons with previously described and measured fossils skulls of Eschrichtius, as well as

modern skulls of $E$. robustus, provide further clarification on the age at death of the two Florida

Holocene gray whales. A juvenile fossil gray whale cranium from Cape Lookout, North Carolina

measured $80 \mathrm{~cm}$ in width across the zygomatic processes (Mead and Mitchell, 1984). This compares to a

width across the zygomatic processes in the two juvenile skulls from Florida of $76 \mathrm{~cm}$ in UF 99000 and 60

cm in UF 69000 (width of squamosals in Table 1). An adult fossil gray whale cranium from Corolla, North

Carolina measured between 130 and $140 \mathrm{~cm}$ across the zygomatics (Mead and Mitchell, 1984). The

width of the occipital condyles in the adult from Corolla is $31 \mathrm{~cm}$, compared to $24 \mathrm{~cm}$ in UF 99000 and

$22 \mathrm{~cm}$ in UF 69000 (Table 1). A juvenile Pliocene gray whale skull (Eschrichtius sp.) from Japan measured

$54 \mathrm{~cm}$ across the paraoccipital processes (Ichishima et al., 2006), compared to widths across the paraoccipitals of $59 \mathrm{~cm}$ (UF 99000) and $45 \mathrm{~cm}$ (UF 69000) in the two Florida juvenile skulls (Table 1). 
333 whales, including both cranial measurements (Sumich et al., 2001) and fusion of cranial sutures (Walsh

334 and Berta, 2011), support our assertion that the Hobe Sound skull was from a calf, younger than 30

335 weeks based on comparative measurements of the paraoccipitals, whereas the larger Jacksonville Beach

336 skull was from an animal older than 30 weeks but less than a year old.

337

338

Our assessment together with earlier studies, are in line with that of two recently reported

Holocene-to- Pleistocene aged gray whale finds in the western Pacific, off Taiwan (Tsai et al. 2014) and Japan (Kimura et al. 2018). The former study identified the paired tuberosities on the occipital shield as diagnostic of Eschrichtiidae sp. (supra). Both Florida gray whale skulls demonstrate these paired tuberosities, in particular UF 99000 (Fig. 3).

Furthermore, the collagen peptide mass fingerprinting results confirm the anatomical identification of whale specific markers presented in Kirby et al. 2013 (specifically, the presence of diagnostic collagen peptide $F$ at 2899). The application of this technique to our other three Pleistocene-aged specimens, however, failed due a lack of preserved collagen in these ancient bones - a result mirrored in the lack of organic fraction available for radiocarbon dating (see below, and also Harvey et al. 2016).

Figure 4. MALDI-ToF Collagen peptide mass fingerprints for specimens UF69000 and UF99000, labelled according to Buckley et al. 2014 and Kirby et al. 2013 modern; inset displays unique gray whale peptide marker at 2899 for both successful specimens. 

morphology of the bones was very well preserved, however, the collagen fraction was almost the bioapatite fraction radiocarbon age estimate was older (33-37.5 ka) than that from the organic, collagen-like, fractions ( 8.3 to $23 \mathrm{ka}$ ). The per mil [\%o] values of $\delta^{13} \mathrm{C}$ reported against VPDB and $\delta^{18} \mathrm{O}$ reported against VPDB and VSMOW and are shown in Table 2, and the AMS dates are displayed in Table

Table 2. Isotopic results for Georgia Bight and Florida specimens of Eschrichtius robustus.

Table3. Radiocarbon ages for Georgia Bight and Florida Specimens

$5.11 \pm 0.04 \%)$ and sample B $(-5.04 \pm 0.04 \%$ ) seem to be more strongly related and are probably from also be from another individual, but because the difference from the other samples is not more than $1 \%$ it is likely that all three of the mysticete whale bone fragments are from the same individual.

\section{Discussion}


385

386

387

388

389

390

391

392

393

394

395

396

397

398

399

400

401

402

403

404

405

406

407

and the dentary based on its previous diagnosis (Garrison, et al, 2012) as this unique mysticete whale but both secure morphological and genomic attributes are lacking for the remainder of our sample three dentary fragments. To include these latter specimens in our assessment of an extirpated population is problematic. We recognize this fact. In the absence of preserved biomolecules, the identity of these remaining specimens has to rest entirely on morphological identification criteria and provenance. In the case of the latter, this is to say that their find locations were in close proximity to UGA 4281 and later discovered cranial elements were identified as Eschrichtius in previous study (Noakes. et al 2013). By parsimony, we argue that if these are whale then they most likely are gray whale.

These observations, in particular the two late Holocene records of juveniles from Florida, potentially provide insight into this species migration route and calving grounds. The eastern Pacific population of gray whales annually migrates from summer grounds in the Bering Sea and Chukchi Sea between Alaska and Russia to winter/calving grounds in Mexico along the western coast of Baja California and the southern Gulf of California (Fig. 5). The best known calving sites of Eschrichtius robustus in the eastern Pacific are located in shallow lagoons along the coast of Baja California between $24^{\circ}$ and $29^{\circ}$ North latitude, including Laguna Ojo de Liebre (also known as "Scammon's Lagoon"), Laguna San Ignacio, and Bahia Magdalena (Rice and Wolman, 1971). The presence of a fossil skull (UF 69000) representing a newborn gray whale calf from Jupiter Island along the southeastern coast of Florida suggests the possibility that this region may have been used as a calving ground by the now-extinct western Atlantic population of gray whales. Along the Atlantic coast of southeastern Florida between $24^{\circ}$ and $29^{\circ} \mathrm{N}$ there are numerous shallow bays and protected lagoons, including Florida Bay, Biscayne Bay, Lake Worth, Hobe Sound, Indian River, Banana River, and Mosquito Lagoon, that would seem to have provided ideal calving grounds for gray whales. 
409 Figure 5. Global distribution of gray whale populations, extant and extinct.

Our results also provide additional insights into the ecological history of this enigmatic species.

411 Current Atlantic Arctic species have evolved over periods whereby adaptation to profoundly different

412 climate regimes was required, such as ca. 12000 years ago when the Bering land bridge closed the

413 western Arctic to Pacific water intrusion (Walsh 2008) or during the retreat of the great ice sheets and

414 the opening continental shelves at the onset of the Holocene (Harington 2008). Climatic changes of the

415 glacial cycles are thought to have been a major driver of arctic population declines and species extinctions, however, there is still not a full understanding of how marine species responded to past

417 climate change.

418

419

420

421

422

424

425

426

427

428

429

430

431

It has been suggested that some Pleistocene cetacean lineages survived into the Holocene and their effective female population size increased rapidly, concurrent with a threefold increase in core suitable habitat (Evans, 1987). For example, using ancient DNA analysis, Foote et al. (2005; 2013) show that the bowhead whale (Balaena mysticetus), shifted its range and tracked its core suitable habitat northwards during the rapid climate change of the Pleistocene-Holocene transition. The case for this type of habitat tracking in Late Pleistocene Atlantic gray whale is not as straightforward. Pyenson and Lindberg (2011) argue for the adaptability of gray whales, suggesting that gray whales survived Pleistocene glacial maxima (e.g. LGM) and maintained substantial population sizes by employing a diverse set of feeding modes, similar to those seen in seasonal resident whales found today between northern Washington State and the coast of Vancouver Island. Molecular data, however, do not support a widespread (maternal) continuity in gray whale lineages across the LGM. In their analysis of Atlantic gray whale fossils, Alter et al (2015) detected little genetic continuity between the late Pleistocene and Holocene populations - within the dataset, only a single sample displayed a lineage that survived post- 
432 LGM. The remaining Holocene samples from both the Western and Eastern basins shared a most recent

433 common ancestor with Pacific gray whales dating to the early to mid-Holocene, suggesting that the

434 majority of the Atlantic Holocene population were the result of a second colonization event when

435 warming temperatures, sea-level rise, and decreases in sea ice permitted passage through the Bering

436 Strait (Alter et al. 2015).

437

438

439

We examined these two hypotheses in light of the range and distribution of the 53 radiocarbon

440

dates for all available Atlantic gray whale finds (Fig. 5). There are 15 late Pleistocene ages that range

441

from >45,200 to 35,520 BP and 38 Holocene ages that range from 10,400 BP to 340 BP (Table 4, Fig.6).

442

These ages are clearly bimodal in their distribution suggesting either that: (1) any population surviving

443

post-LGM is geologically "invisible", due to a lack of fossil evidence; or (2) the lack of finds reflects their

true absence, indicating a significant decline or even the effective extirpation of gray whales across the

north Atlantic Ocean in the period between $\sim 40 \mathrm{ka}$ and $\sim 11 \mathrm{ka}$. The argument in favor for the latter may

be further supported by geologic evidence for a much-reduced habitat in the north Atlantic during LGM

shelves (Alter et al. 2015; Garrison et al. 2008; 2012; Harris et al. 2013). Fossil evidence for the gray

whale, however, may yet be found for the post- $40 \mathrm{ka}-11 \mathrm{ka}$ interval on areas of the Atlantic

in our study for recent western Atlantic Ocean finds are in good alignment with these (predominantly 
456

457

458

459

460

461

462

463

464
Figure 6. Scatter plot of 53 radiocarbon ages for Atlantic Basin gray whale finds, with gap between $\sim 35,000$ and $\sim 11,000$ BC (Logarithmic scale, base 10).

Table 4 Pleistocene and Holocene eastern and western North Atlantic gray whale specimens 
465

466

467

468

469

470

471

472

473

474

475

476

477

478

479

480

481

482

483

484

485

486

487

488

\section{Conclusions}

In our results, collagen peptide mass fingerprinting and paleontological diagnoses confirm the two Florida finds to be the Atlantic gray whale, Eschricthius robustus. Due to the lack of preserved collagen in the three Pleistocene aged fragmentary specimens, we cannot confirm the species identities through biomolecular analyses; paleontological diagnoses, however, support for our identification of the relatively well-preserved Georgia Bight dentary as gray whale as well is based on our previous diagnosis (Garrison, et al, 2012). Thus, the existence of both Pleistocene and Holocene gray whale populations in the western Atlantic Ocean are supported by these fossils and their radiocarbon dates.-The results of our study may help explain the Late Quaternary occurrences of gray whales in the Georgia Bight and along the Atlantic Coast of Florida, in particular the two late Holocene records of juveniles from Florida. The presence of newborn gray whale calf's skull from Jupiter Island as well as a juvenile gray whale's dentary from the Georgia Bight suggests that the region between $24^{\circ}$ and $29^{\circ} \mathrm{N}$ may have been used as a calving ground by the now-extinct western Atlantic population of gray whales

\section{ACKNOWLEDGMENTS}

We thank the following colleagues and/or agencies for their assistance in the research that contributed to this article: Drs. Brenna McLeod and Tim Frazier, St. Mary's University, Halifax, Nova Scotia, Canada; Dr. Michael Hofreiter, Potsdam University, Germany ;

Klaas Post, Natural History Museum, Rotterdam, The Netherlands;

Keri Rowsell for technical assistance, University of York, UK;

C.W. (Kees) Moeliker \& H.P. (Henry) van der Es, Natural History Museum, Rotterdam, The Netherlands; Wendy van Bohemen, Naturalis Biodiversity Center, Leiden, The Netherlands;

Dr. Scott E. Noakes, Center for Applied Isotope Studies, University of Georgia, Athens, GA; 
489 Dr. Mark Williams; Amanda Thompson; Isabelle Cantin - The Laboratory for Archaeology, University of

490 Georgia, Athens, GA.;

491 Dr. Nicholas Pyenson, Smithsonian Institution, Washington, DC; and the

492 National Oceanic and Atmospheric Administration (NOAA).

493

494

495

REFERENCES

496

497

Alter, E., M. Meyer, KI. Post, P. Czechowski, P. Gravlund, C. Gaines, H. C. Rosenbaum, K. Kaschner, S. T.

498

Turvey, J. van der Plicht, B. Shapiro and M. Hofreiter. 2015. Climate impacts on trans-ocean dispersal

499

and habitat in gray whales from the Pleistocene to 2100. Molecular Ecology 24.7: 1510-1522

500

501

Arnason, U., S. Gretarsdottir and B. Widegren. 1992. Mysticete (baleen whale) relationships based upon

502

the sequence of the common cetacean DNA satellite. Molecular and Biological Evolution 9:1018-1028.

503

Available at http://mbe.oxfordjournals.org/content/9/6/1018.full.pdf

504

505

Arnason, U. and A. Gullberg. 1993. Comparison between the complete mtDNA sequences of the blue

506

and the fin whale, two species that can hybridize in nature. Journal of Molecular Evolution 37:312-322.

507

Available at http://www.springerlink.com/content/q21734t368661hk3/fulltext.pdf

508

509

Arnason, U. and A. Gullberg. 1994. Relationship of baleen whales established by cytochrome b gene

510

sequence comparison. Nature 367:726-728. Avalable at

511

http://www.nature.com/nature/journal/v367/n6465/pdf/367726a0.pdf

512 
513 Arnason, U. and A. Gullberg. 1996. Cytochrome b nucleotide sequences and the identification of five

514 primary lineages of extant cetaceans. Molecular Biology and Evolution 13:407-417. Available at

515 http://mbe.oxfordjournals.org/content/13/2/407.full.pdf

516

517 Barnes, L.G. and S.A. McLeod. 1984. The fossil record and phyletic relations of Gray whales. In: M.L.

518 Jones S.L. Swartz and S. Leatherwood, eds. The Gray Whale, Eschrichtius robustus. Academic Press, Inc.

519 New York. Pp. 1-32.

520

521 Bischonti, M. 2008. Morphology and phylogenetic relationships of a new

522 eschrichtiid genus (Cetacea; Mysticeti) from the Early Pliocene of northern Italy,

523 Zoological Journal of the Linnean Society, 153:161-186

524

525

Brisson, M.J. 1762. Le regnum animale in classes IX distributum, sive synopsis methodica

sistens geenralem animalium distributiononem in classes $I X, \&$ duarum primarum classium,

527

quadrapedum scilicet \& cetaceorum, particularem dibvisionem in ordines, sectiones, genera \&

528 species. T. Haak. Paris. 296 p.

529

530

Bryant, P.J. 1995. Dating remains of Gray Whales from the Eastern North Atlantic, Journal of

531 Mammalogy 76(3):857-61.

532

533 Buckley, M., S. Fraser, J. Herman, N.D. Melton, J. Mulville and A.H. Pálsdóttir. 2014. Species

534 identification of archaeological marine mammals using collagen fingerprinting. Journal of Archaeological 535 Science 41:631-641.

536 
537 Cherkinsky, A. 2009. "Can We Get A Good Radiocarbon Age from "Bad Bone"? Determining the

538 Reliability of Radiocarbon Age from Bioapatite." Radiocarbon 51(2):647-655.

539

540 Collins, M., M. Buckley, H. H. Grundy, J. Thomas-Oates, J. Wilson and N. van Doorn. 2010. ZooMS: the 541 collagen barcode and fingerprints. Spectroscopy Europe 22:6.

542

543

Dalén, L., V. Nyström, C. Valdiosera, M. Germonpré, M. Sablin, E. Turner, A. Angerbjörn, J.L. Arsuaga and

544 A. Götherström. 2007. Ancient DNA reveals lack of postglacial habitat tracking in the arctic fox.

545 Proceedings of the National. Academy of Sciences. U. S. A. 104:6726-6729.

546

547 de Bruyn, M., A.R. Hoelzel, G.R. Carvalhoand and M. Hofreiter. 2011. Faunal histories from Holocene

548 ancient DNA. Trends in Ecological Evolution 26, 405-413.

549

550

Deméré, T.A., McGowen, M.R., Berta, A. and Gates, J. 2008. Morphological and

551 molecular evidence for a stepwise evolutionary transition from teeth to baleen in mysticete

552 whales. Systematic Biology, 57(1):15-37.

553

554 Ellerman, J.R. and J.C.S. Morrison-Scott. 1951. Checklist of Palaearctic

555 and Indian Mammals, 1758-1946. British Museum (Natural History), London. 810 p.

556

557 Evans, S. and J. Mulville. 2018. Finding Moby: Identifying whales in the archaeological record. The SAA

558 Archaeological Record, 18(4): 31-37.

559

560 Garrison, E.G., McFall, G. and Noakes, S.E. 2008. Shallow marine margin sediments, 
561 modern marine erosion and the fate of sequence boundaries, Georgia Bight (USA).

562 Southeastern Geology, 45: 127-142.

563

564 Garrison, E. G., G. McFall, A. Cherkinsky and S.E. Noakes. 2012. Discovery of a Pleistocene mysticete 565 whale, Georgia Bight (USA). Palaeontologica Electronica 15(3):10.

566

567 George, J. C., J. Zeh, R. Suydam and C. Clark. 2004. Abundance and population trend (1978-2001) of 568 western Arctic bowhead whales surveyed near Barrow, Alaska. Marine Mammal Science,20:755-773.

569

570

Gray, J.E. 1846. On British Cetacaea. Annals and Magazine of Natural History, [ser. 1], 17:83.

571

572

Harington, C. R. 2008. The evolution of Arctic marine mammals. Ecological Applications 18(2):S23-S40.

573

574

Harvey, V. L., V.M. Egerton, A.T. Chamberlain, P.L. Manning, P. L., and M. Buckley. 2016. Collagen

575 Fingerprinting: A New Screening Technique for Radiocarbon Dating Ancient Bone. PloS One, 11(3), 576 e0150650.

577

578

Hofreiter, M. 2008. Long DNA sequences and large data sets: investigating the Quaternary via ancient

DNA. Quaternary Science Reviews 27:2586-2592.

580

581 Hofreiter, M., D. Serre, N. Rohland, G. Rabeder, D. Nagel, N. Conrad. S. Münzel and S. Pvääbo . 2004.

582 Lack of phylogeography in European mammals before the last glaciation. Proceedings of the National.

583 Academy of Sciences. U. S. A. 101:12963-12968.

584 
585 Hofreiter, M. and J. Stewart. 2009. Ecological change, range fluctuations and population dynamics 586 during the Pleistocene. Current Biology 19:R584-94.

587

588 Icshishima, H., Sato, E., Sagayama, T. and Kimura, M. 2006. The oldest record of

589 Eschrichtidiiade (Cetacea: Mysticeti) from the Late Pliocene, Hokkaido, Japan, 590 Journal of Paleontology, 80(2): 367-379

591

592 Kimura, T., Y. Hasegawa. and N. Kohno. 2017. A new species of the genus Eschrichtius (Cetacea:

593 Mysticeti) from the Early Pleistocene of Japan. Paleontological Research, 22:, 1-19.

594 (doi:10.2517/2017PR007).

595

596 Kirby, D.P., M. Buckley, E. Promise, S.A. Trauger and T.R. Holdcraft. 2013. Identification of collagen597 based materials in cultural heritage. Analyst 138:4849-4858.

598

599

LeGeros ,R.Z. and J.P. LeGeros . 1984. Phosphate minerals in human tissues. In Phosphate Minerals (Eds.

600 J.O.Nriagu JO, and P.B. Moore). Springer-Verlag, Berlin Germany. Pp. 352-85.

601

602

Lilljeborg, W. 1861. Hvalben, Funna i jorden paa, Gräsön i Roslagen i Sverige. Forh. Skand. Naturf., $8^{\text {th }}$ 603 Mote. 1860 , p. 599-616.

604

605

Lilljeborg, W. 1867. On two subfossil whales discovered in Sweden. Nova Acta Regiae Societatis

606 Scientiarum Upsaliensis [3] 6(2):1-48.

607 
608 Lindquist, O. 2000. The North Atlantic gray whale (Eschrichtius robustus): An historical outline based on

609 Icelandic, Danish-Icelandic, English and Swedish sources dating from ca 1000 AD to 1792. Occasional

610 Papers. The Carnegie Trust for Universities of Scotland. Universities of St. Andrews and Stirling.

611

612 Linnaeus, C. 1758. Systema Naturae per regna tria naturae, secundum classis, ordines,

613 genera, species cum characteribus, differentiis, synoymis, locis. Tenth ed. Vol. 1.Laurentii

614 Salvii, Stockholm. 824 p.

615

616 McLeod, B. A., M.W. Brown, M.J. Moore, W. Stevens, S.H. Barkham and B.N. White. 2008. Bowhead

617 whales, and not right whales, were the primary target of 16th-to 17th-century Basque whalers in the 618 western North Atlantic. Arctic: 61-75.

619

620

Mead, J.G. and E. Mitchell. 1984. Atlantic Gray Whales. In: Jones M.L., Swartz S.L., Leatherwood S., eds.

621 The Gray Whale, Eschrichtius robustus. Academic Press, Inc. New York. Pp. 33-53.

622

623 Noakes, S. E., E.G. Garrison and G. McFall. 2009. Underwater paleontology: recovery of a prehistoric

624 whale mandible offshore Georgia. In: Pollock N.W. ed. Diving for Science 2009. Proceedings of the

625 American Academy of Underwater Sciences 28th Symposium, Atlanta, GA. Pp. 245-251.

626

627 Noakes, S. E., N.D. Pyenson and G. McFall. 2013. Late Pleistocene gray whales (Eschrichtius robustus)

628 offshore Georgia, USA, and the antiquity of gray whale migration in the North Atlantic Ocean.

629 Palaeogeography, Palaeoclimatology and Palaeoecology 392:502-509.

630 
631 Pyenson, N. D. and D.R. Lindberg. 2011. What happened to gray whales during the Pleistocene? The 632 ecological impact of sea-level change on benthic feeding areas in the North Pacific Ocean. PLoS One 633 6(7):e21295.

634

635 Rastogi, T., M.W. Brown, B.A. McLeod, T.R. Frasier, R. Grenier, S.L. Cumbaa, J. Nadarajah and B.N.

636 White. 2004. Genetic analysis of 16th-century whale bones prompts a revision of the impact of Basque

637 whaling on right and bowhead whales in the western North Atlantic. Canadian Journal of Zoology 638 82(10):1647-1654.

639

640 Rice, D. W. and A. A. Wolman. 1971. The life history and ecology of the gray whale (Eschrichtius 641 robustus). American Society of Mammalogists, Special Publication 3:1-142.

642

643 Sasaki, T., M. Nikaido, H. Hamilton, M. Goto, H. Kato, N. Kanda, L. A. Pastene, Y. Cao, R.E. Fordyce, M. 644 Hasegawa and N. Okada. 2005. Mitochondrial phylogenetics and evolution of mysticete whales. 645 Systematic Biology 54(1):77-90.Available at http://www.jstor.org/pss/20061212.

646

647 Steeman, M.E. 2007. Cladistic analysis and a revised classification of fossil and recent 648 mysticetes. Zoological Journal of the Linnean Society, 150: 875-894.

649

650

651 Stewart, J.R. 2009. The evolutionary consequence of the individualistic response to climate change.

652 Journal of evolutionary biology, 22(12):2363-2375.

653 
654 Strohalm, M., M. Hassman, B. Kosata, and M. Kodícek. 2008. mMass data miner: an open source 655 alternative for mass spectrometric data analysis. Rapid Communications in Mass Spectroscopy 22:905656908.

657 Tsai, C.-H., Fordyce, R.E., Chang, C.-H. and Lin, L.-K. 2014. Quaternary fossil gray whales from Taiwan. 658 Paleontological Research, 18: 82-93. (doi:10.2517/2014pr009).

659

660 True, F. W. 1983. The whalebone whales of the western North Atlantic. Smithsonian Institution Press, 661 Washington, DC. (True, F.W. 1904. The whalebone whales of the western North Atlantic. Smithsonian 662 Contributions to Knowledge, 33:1-332.reprinted).

663

664 Tsai, C-H., R.E. Fordyce, C-H. Chang and L-K. Lin. 2014. Quaternary fossil gray whales from Taiwan. 665 Paleontology Research 18(2):82-93.

666

Van Deinse, A.B. and G.C.A. Junge. 1937. Recent and older finds of the California gray whale in the 668 Atlantic. Temminckia 2: 161-188.

669

670

Vogel, J.S., J.R. Southon, D.E. Nelson and T.A. Brown. 1984. Performance of catalytically condensed

671 carbon for use in accelerator mass spectrometry. Nuclear Instruments and Methods in Physics Research

672 Section B: Beam Interactions with Materials and Atoms 5(2):289-293.

673

674 Walsh, J. E. 2008. Climate of the Arctic marine environment. Ecological Applications 18(2):S3-S22.

675

676

677 
683

684

685

686

687

688

689

690

691

692

693

694

695

696 
Figure 1

Location map J-Y Reef to Hobe Beach 


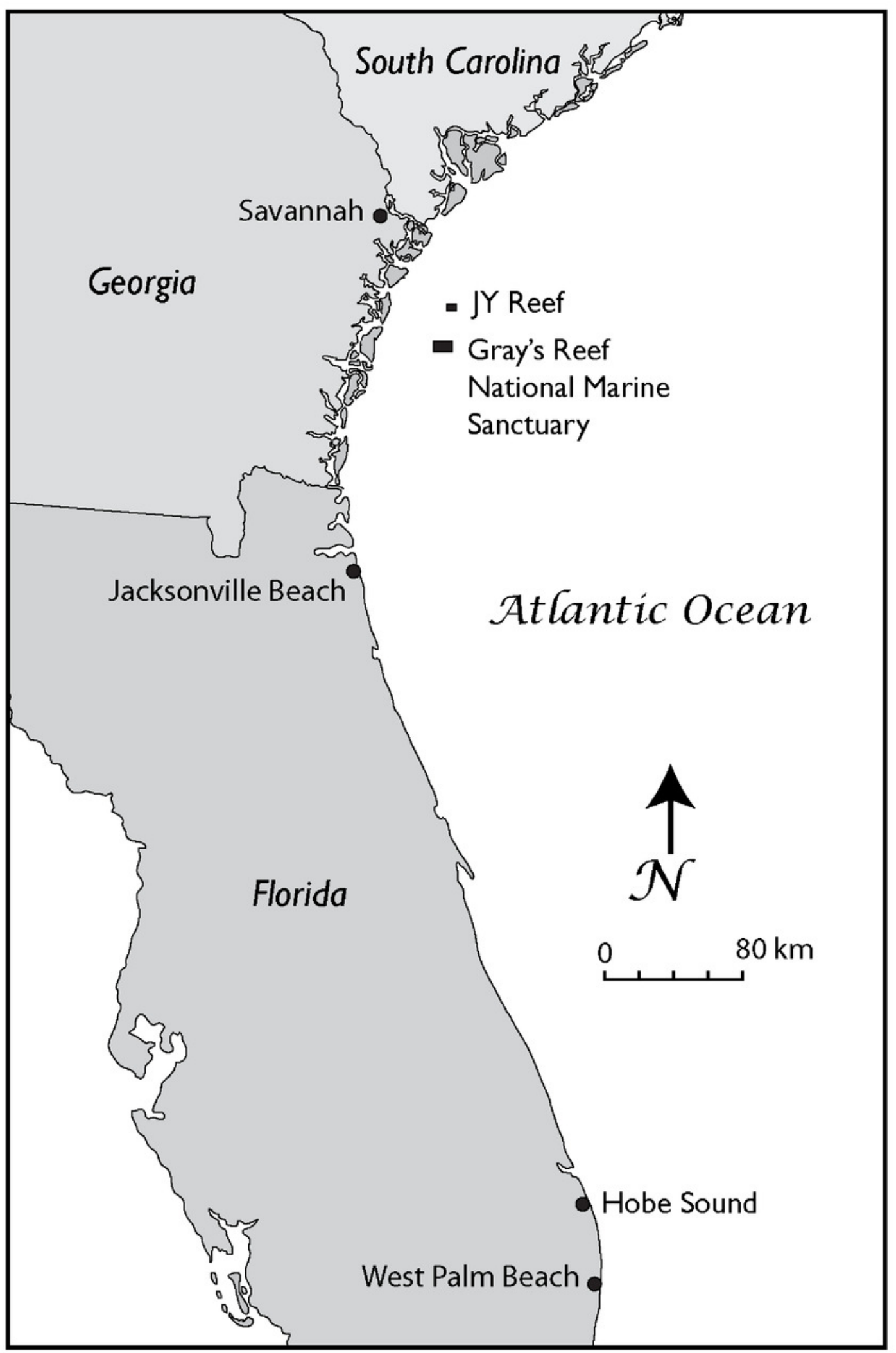


Figure 2

The late Pleistocene and Holocene specimens of the gray whale (Eschrichtius robustus), Research Ledge site, JY Reef, Georgia Bight used in this study.
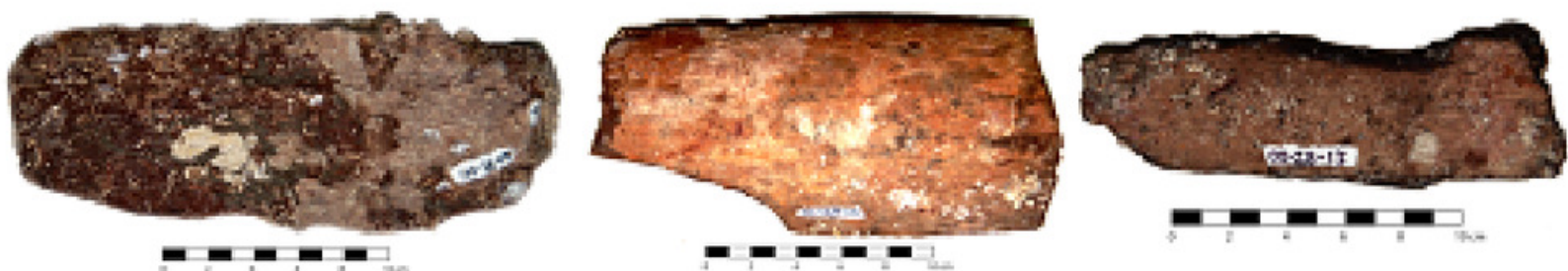

A.
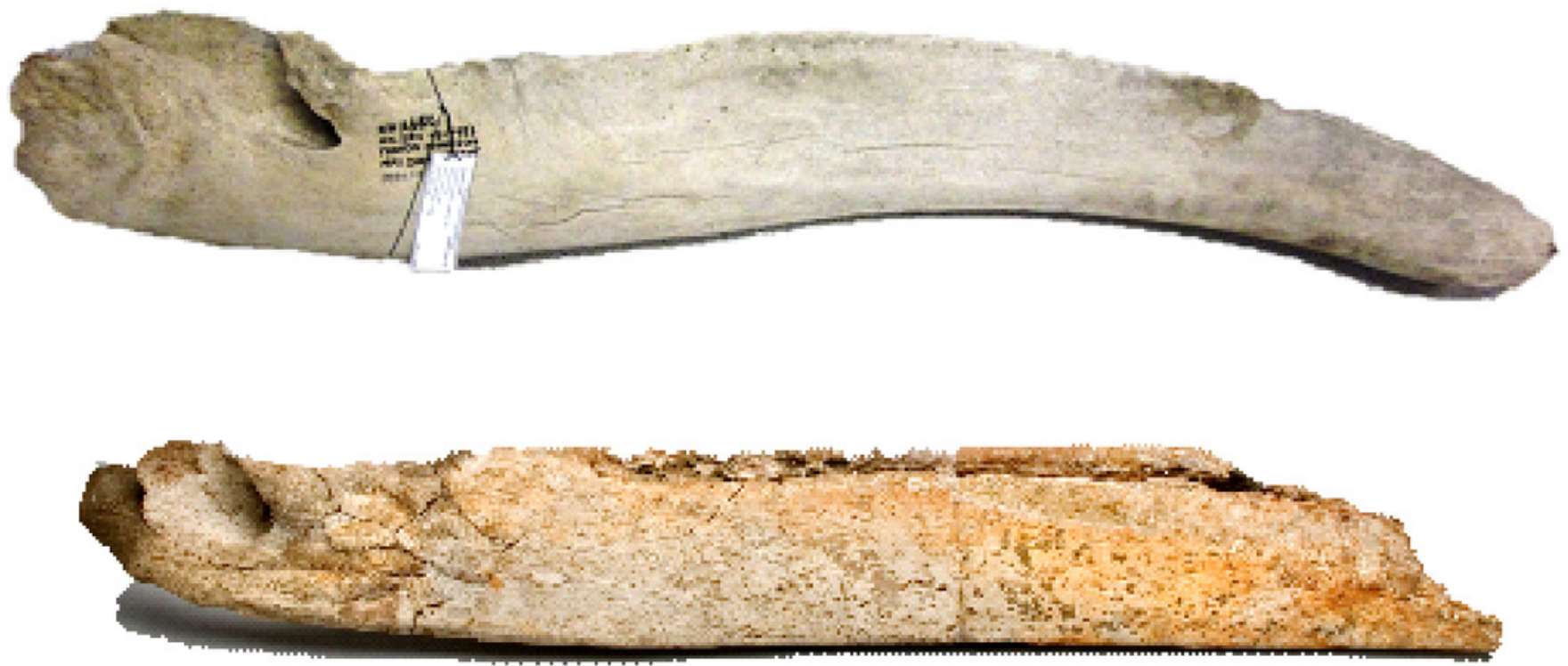

B. 
Figure 3

Two partial Holocene skulls gray whales (Eschrichtius robustus) from Florida (USA).

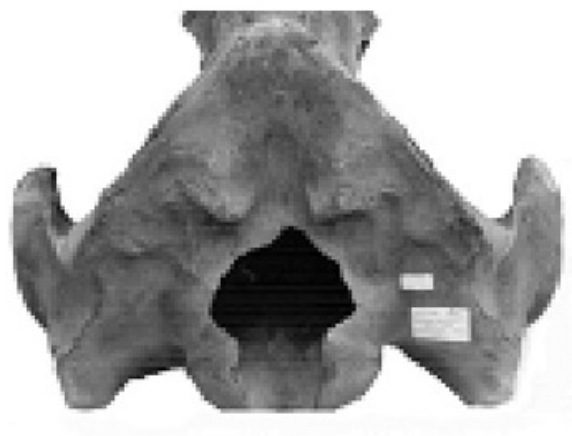

A

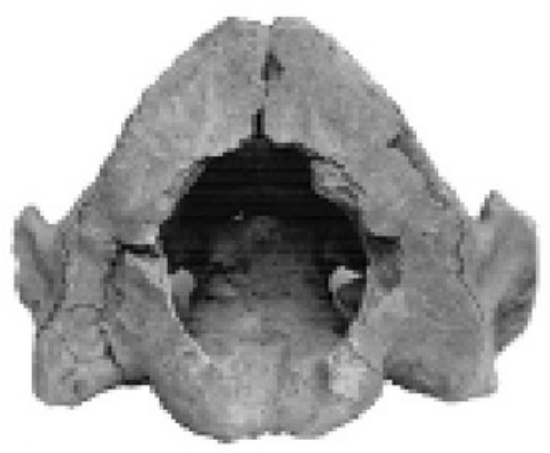

D

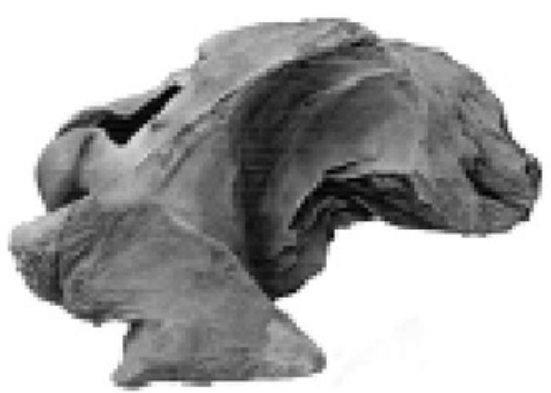

B

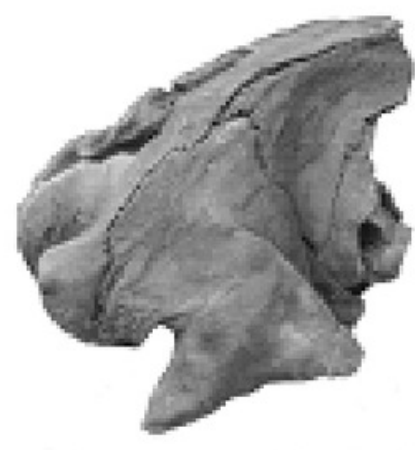

$E$

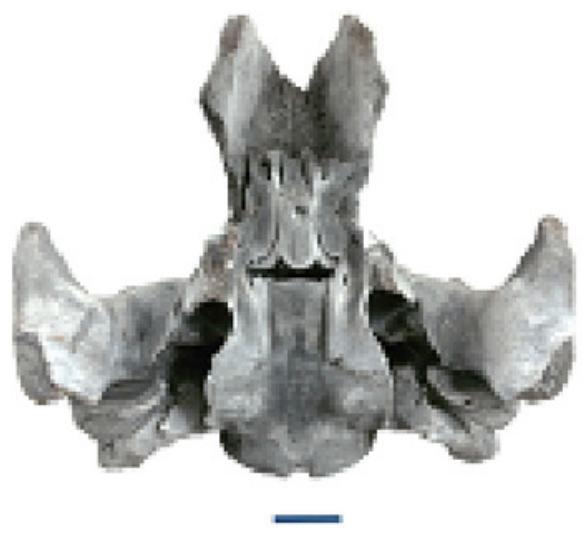

C

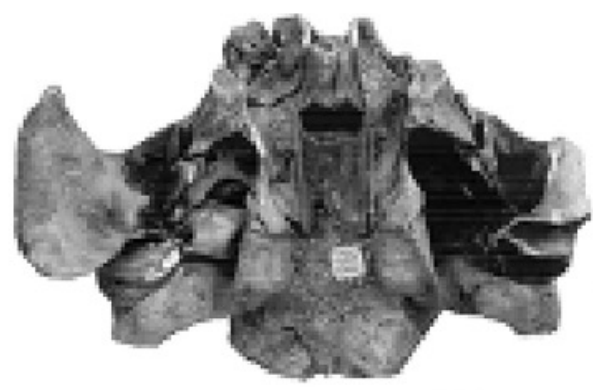

$\mathrm{F}$
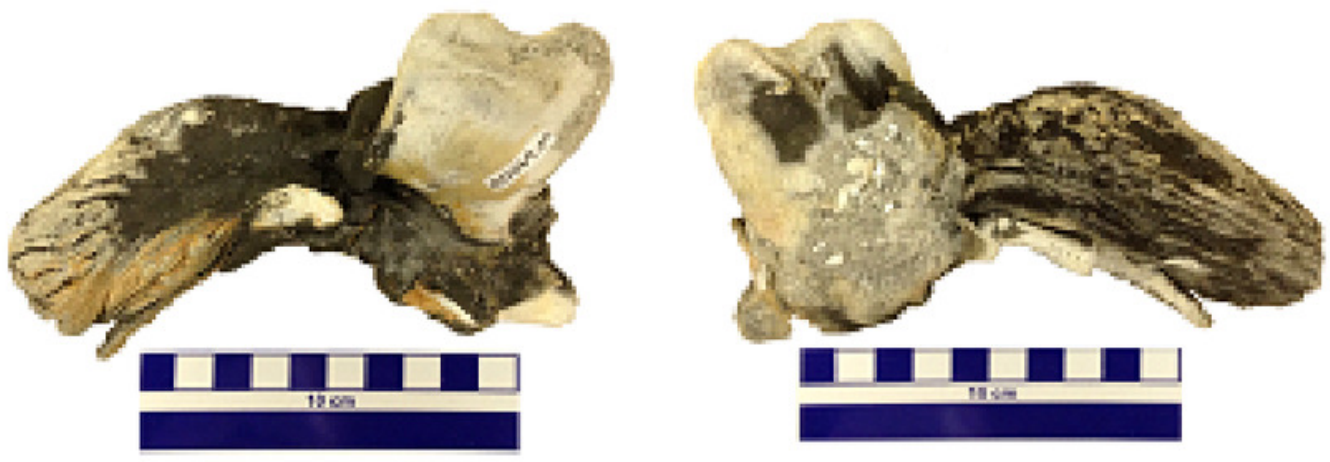
Figure 4

MALDI-ToF Collagen peptide mass fingerprints for specimens UF69000 and UF99000, labelled according to Buckley et al. 2014 and Kirby et al.

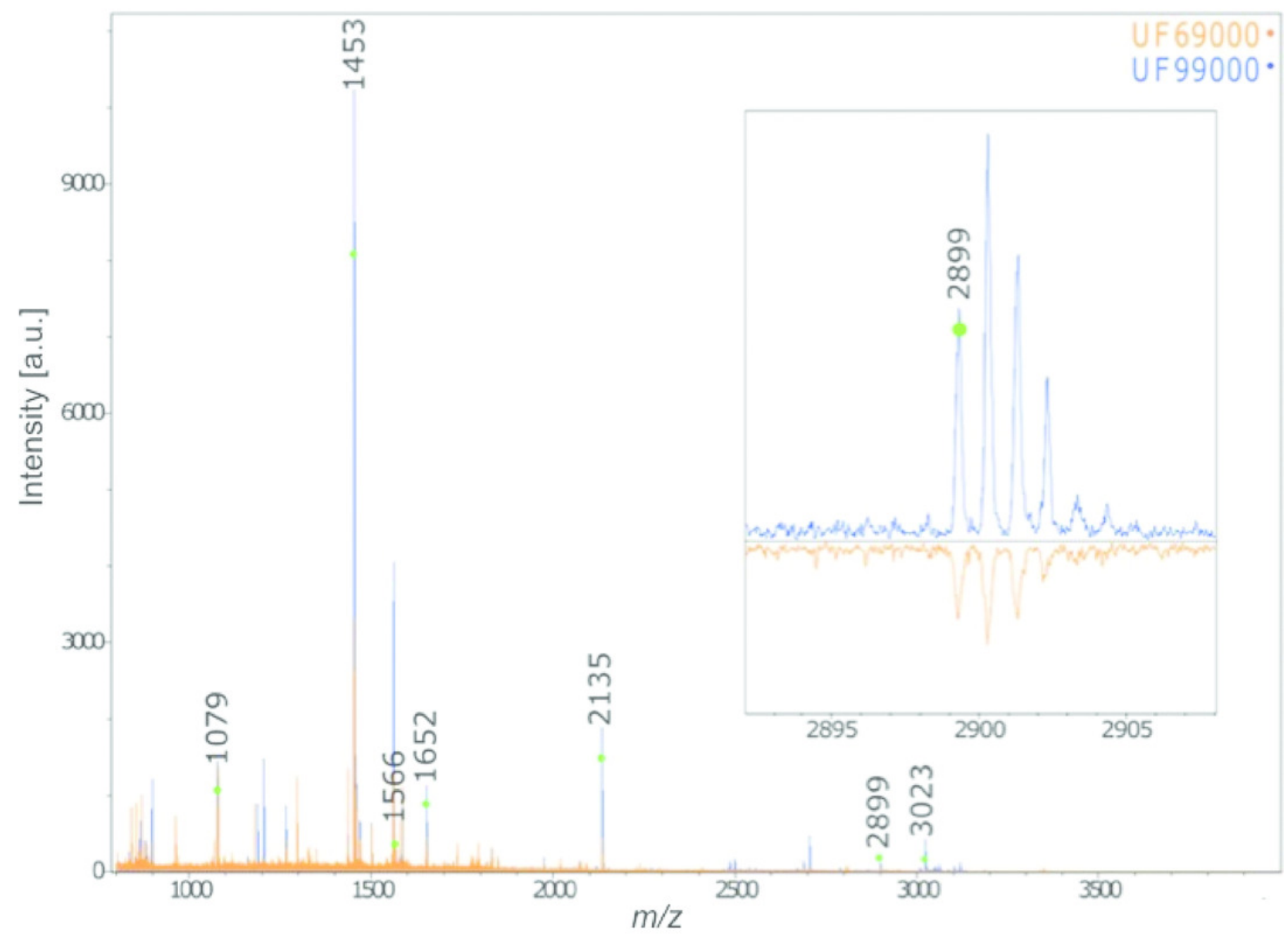


Figure 5

Global distribution of gray whale fossil finds.

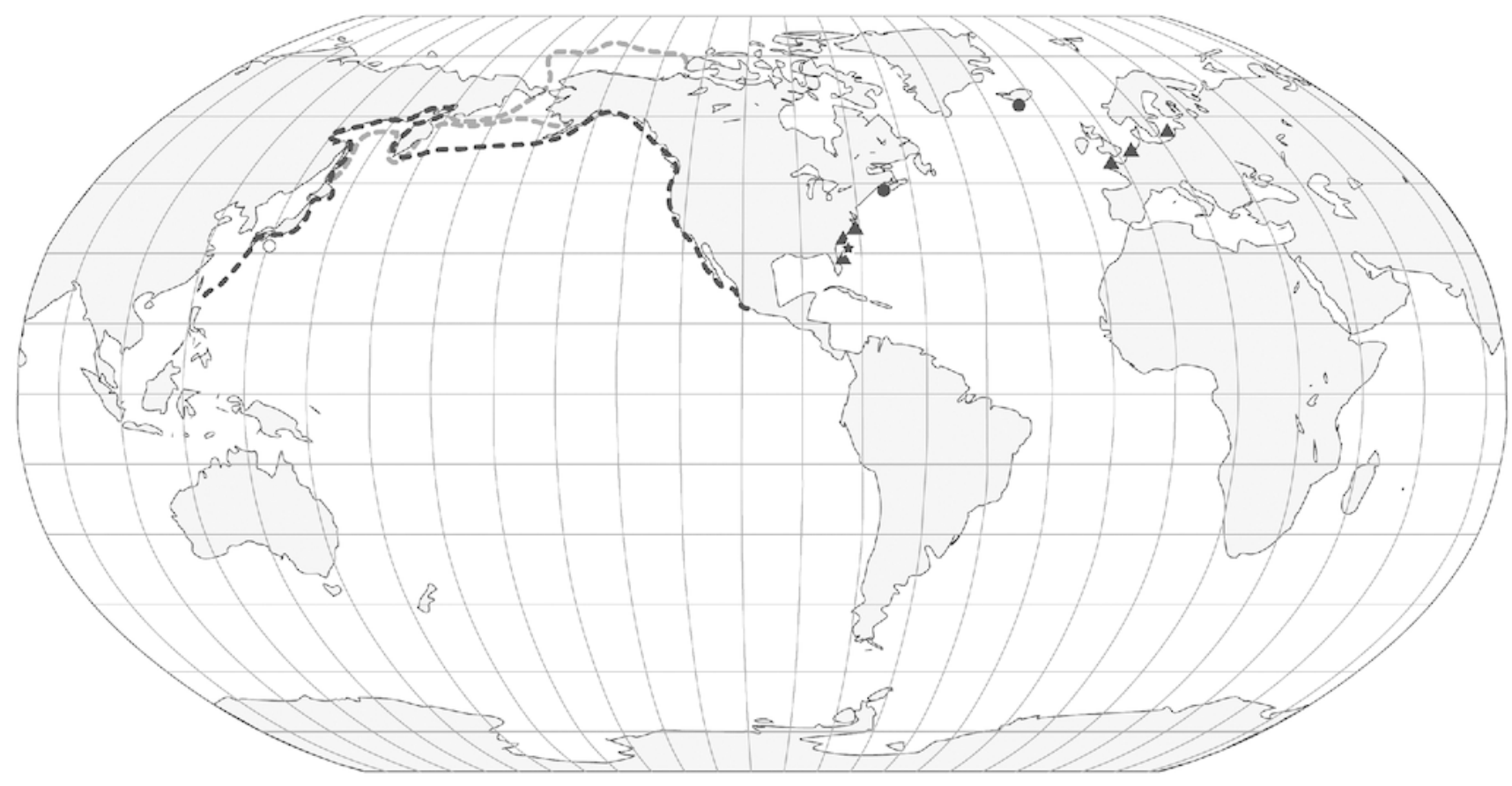

- Fossil evidence for gray whales

- Historical evidence for gray whales

th Fossil evidence for gray whales, this study

Summer feeding grounds

-.---- Gray Whale migration route 
Figure 6

Scatter plot of 53 radiocarbon ages for Atlantic Basin gray whale finds, with gap between $\sim 35,000$ and $\sim 11,000$ BC (Logarithmic scale, base 10).

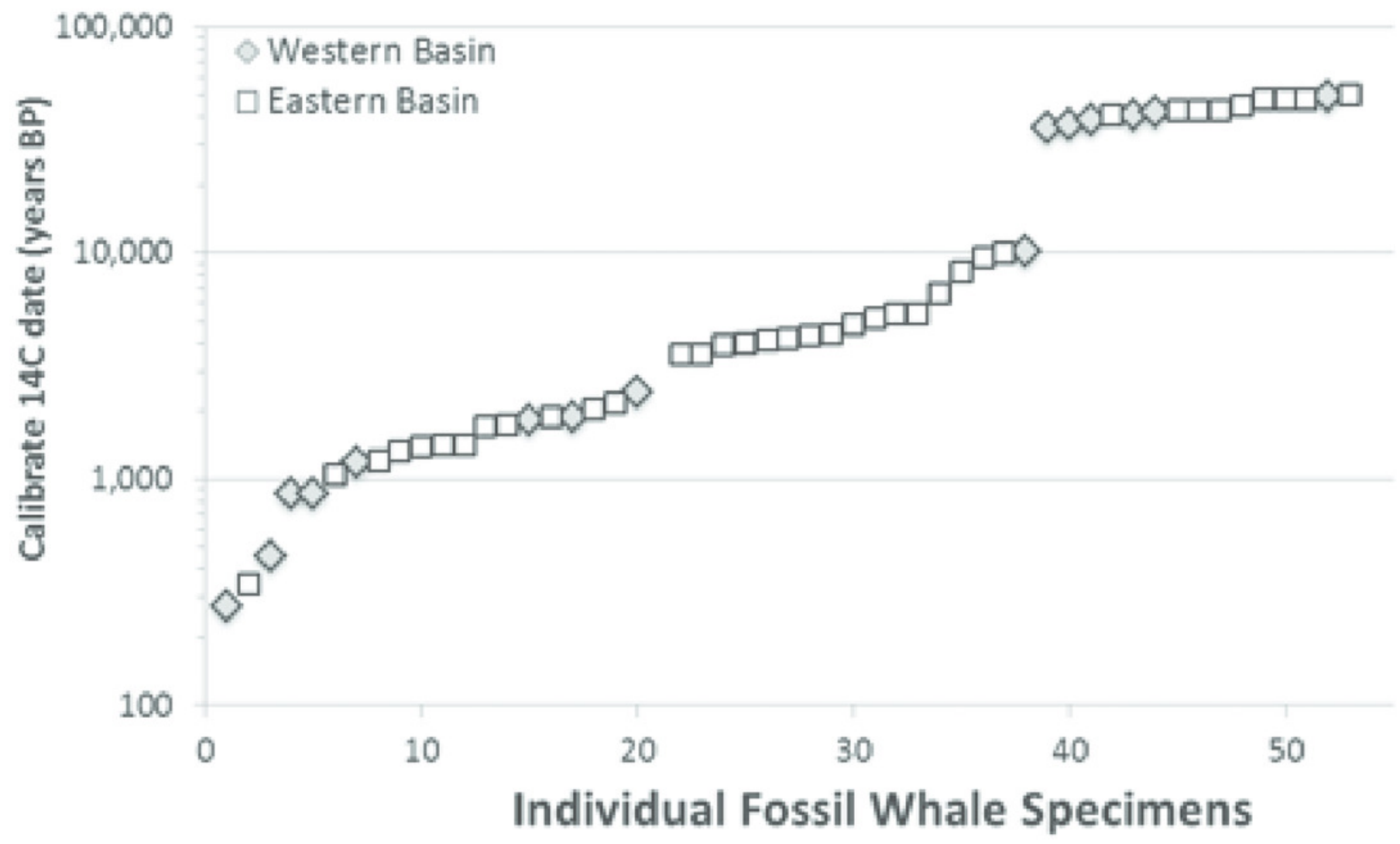




\section{Table $\mathbf{1}$ (on next page)}

Cranial measurements of Quaternary gray whale skulls

Cranial measurements (in $\mathrm{cm}$ ) of Quaternary gray whales (Eschrichtius robustus) skulls from Florida (this study). 
1 Table 1. Cranial measurements (in $\mathrm{cm}$ ) of Quaternary gray whale (Eschrichtius robustus) skulls

2 from Florida (this study).

3

\begin{tabular}{c|c|c|c} 
Locality \& & width of & width of & width of \\
Catalogue \# & squamosals & paraocciptals & supraocciptals
\end{tabular}

\begin{tabular}{c|c}
$\begin{array}{c}\text { width of occipital } \\
\text { condyles }\end{array}$ & height of skull \\
\hline
\end{tabular}

Hobe
Sound
NWR
UF 69000

Jacksonville

60

45

39

22

41

Beach

UF 99000

4

5 


\section{Table 2 (on next page)}

Isotopic results for Georgia Bight secimens.

Isotopic results for the Georgia Bight and Florida specimens of Eschrichtius robustus. 
1 Table 2. Isotopic results for Georgia Bight and Florida specimens of Eschrichtius robustus.

\begin{tabular}{|c|c|c|c|}
\hline Laboratory \# & $\delta^{13} \mathrm{C}[\%$ \% vs. VPDB & $\delta^{18} \mathrm{O}[\%$ ] vs. VPDB & $\delta^{18} \mathrm{O}[\% \circ]$ vs. VSMOW \\
\hline Dentary A (00-28-09) & -5.11 & 0.22 & 31.14 \\
\hline Dentary B (00-28-10) & -5.04 & 0.14 & 31.05 \\
\hline Dentary C (00-28-13) & -4.80 & 0.92 & 31.86 \\
\hline 4281 (dentary) & -6.62 & -10.34 & 20.25 \\
\hline UF 69000 (cranium) & -9.5 & - & - \\
\hline UF 99000 (cranium) & -10.3 & - & - \\
\hline
\end{tabular}

2

3 


\section{Table 3(on next page)}

Radiocarbon ages for specimens.

Radiocarbon ages for Georgia Bight and Florida specimens. 
1 Table3. Radiocarbon ages for Georgia Bight and Florida Specimens

2

\begin{tabular}{|c|c|c|c|c|c|c|}
\hline UGA \# & Element & Condition & Find Location & $\begin{array}{r}{ }^{14} \text { C age, } \\
\text { years BP }\end{array}$ & $\begin{array}{l}\text { Reservoir } \\
\text { effect, } \mathbf{R}\end{array}$ & $\begin{array}{c}\text { Calendar age, BP 95.4\% } \\
\text { probability }\end{array}$ \\
\hline $\mathbf{4 2 8 1}$ & Dentary & fossil & J-Reef & $36,570 \pm 300$ & $-120 \pm 78$ & $40230-41550$ \\
\hline $\mathbf{4 2 1 4}$ & Dentary? & fossil & J-reef & $33,520 \pm 160$ & $-120 \pm 78$ & $36240-37460$ \\
\hline $\begin{array}{c}\text { UF } \\
\mathbf{6 9 0 0 0}\end{array}$ & Cranium & fossil & $\begin{array}{c}\text { Jacksonville } \\
\text { Beach, Florida }\end{array}$ & $2130+/-25$ & $-90 \pm 131$ & $1500-2150$ \\
\hline $\begin{array}{c}\text { UF } \\
99000\end{array}$ & Cranium & fossil & $\begin{array}{c}\text { Hobe Sound, } \\
\text { Florida }\end{array}$ & $2190+/-20$ & $-90 \pm 131$ & $1570-2220$ \\
\hline
\end{tabular}

3 


\section{Table 4 (on next page)}

Pleistocene and Holocene Atlantic gray whale specimens.

Pleistocene and Holocene eastern and western Atlantic gray whale spoecimens. 
2 Table 4. Pleistocene and Holocene eastern and western North Atlantic gray whale specimens

\begin{tabular}{|c|c|c|c|c|}
\hline Region & Date found & Cal yr BP & Citation & Current Location \\
\hline \multicolumn{5}{|c|}{ Gray whale - Eastern Atlantic Basin } \\
\hline Pentuan, England & 1829 & $1,329 \pm 195$ & Flower 1872; Bryant 1995; Alter et al. 2015 & unknown \\
\hline Gräsö, Sweden & 1859 & $4,395 \pm 155$ & Lilljeborg 1861; Persson 1986 & unknown \\
\hline Babbacombe Bay, England & 1861 & & Gray 1864 & unknown \\
\hline Babbacombe Bay, England & 1865 & $340 \pm 260$ & $\begin{array}{c}\text { Gray 1866; Pengelly 1865, 1878; Bryant 1995; Alter } \\
\text { et al. } 2015\end{array}$ & unknown \\
\hline ljmuiden, Netherlands & 1879 & $8,330 \pm 85$ & Van Deinse and Junge 1937; Bryant 1995 & National Natural History Museum Naturalis, Leiden \\
\hline Ijmuiden, Netherlands & 1916 & 1,400 & Van Deinse and Junge1937; Bryant 1995 & National Natural History Museum Naturalis, Leiden \\
\hline $\begin{array}{l}\text { Wieringermeer- } \\
\text { Polder,Netherlands }\end{array}$ & 1935 & $4,195 \pm 45$ & Van Deinse and Junge1937; Bryant 1995 & National Natural History Museum Naturalis, Leiden \\
\hline $\begin{array}{l}\text { Oostduinkerke- } \\
\text { Koksijde,Belgium }\end{array}$ & 1978 & $2,024 \pm 110$ & Asselberg 1981; Bryant 1995 & Unknown \\
\hline North Sea, Netherlands & 2005 & $42,800 \pm 4100-2700$ & Post 2005 & Natural History Museum, Rotterdam \\
\hline North Sea, Netherlands & 2005 & $>45,200$ & Mol et al. 2006 & Natural History Museum, Rotterdam \\
\hline North Sea, Netherlands & 2001 & $1150-1270$ & Alter et al. 2015 & Natural History Museum, Rotterdam \\
\hline North Sea, Netherlands & No Data & $1350-1500$ & Alter et al. 2015 & Unknown \\
\hline North Sea, Netherlands & 1997 & $1350-1500$ & Alter et al. 2015 & Natural History Museum, Rotterdam \\
\hline North Sea, Netherlands & 2003 & $2650-2730$ & Alter et al. 2015 & Natural History Museum, Rotterdam \\
\hline North Sea, Netherlands & No data & $>48000$ & Alter et al. 2015 & Unknown \\
\hline North Sea, Netherlands & 2005 & $>48000$ & Alter et al. 2015 & Natural History Museum, Rotterdam \\
\hline North Sea, Netherlands & 2003 & $42500-43300$ & Alter et al. 2015 & Natural History Museum, Rotterdam \\
\hline North Sea, Netherlands & 1879 & $9470-9550$ & Alter et al. 2015 & National Natural History Museum Naturalis, Leiden \\
\hline North Sea, Netherlands & 1916 & $1600-1800$ & Alter et al. 2015 & National Natural History Museum Naturalis, Leiden \\
\hline North Sea, Netherlands & 1935 & $4760-4850$ & Alter et al. 2015 & National Natural History Museum Naturalis, Leiden \\
\hline North Sea, Netherlands & No data & $4950-5250$ & Alter et al. 2015 & Natural History Museum, Rotterdam \\
\hline North Sea, Netherlands & 1954 & $3830-3960$ & Alter et al. 2015 & Natural History Museum, Rotterdam \\
\hline North Sea, Netherlands & 1994 & $960-1120$ & Alter et al. 2015 & Natural History Museum, Rotterdam \\
\hline North Sea, Netherlands & 1995 & $4230-4420$ & Alter et al. 2015 & Natural History Museum, Rotterdam \\
\hline North Sea, Netherlands & 1996 & $>48000$ & Alter et al. 2015 & Natural History Museum, Rotterdam \\
\hline North Sea, Netherlands & 2005 & $1820-1950$ & Alter et al. 2015 & Natural History Museum, Rotterdam \\
\hline North Sea, Netherlands & 2005 & $>50000$ & Alter et al. 2015 & Natural History Museum, Rotterdam \\
\hline North Sea, Netherlands & 2005 & $3480-3630$ & Alter et al. 2015 & Natural History Museum, Rotterdam \\
\hline
\end{tabular}




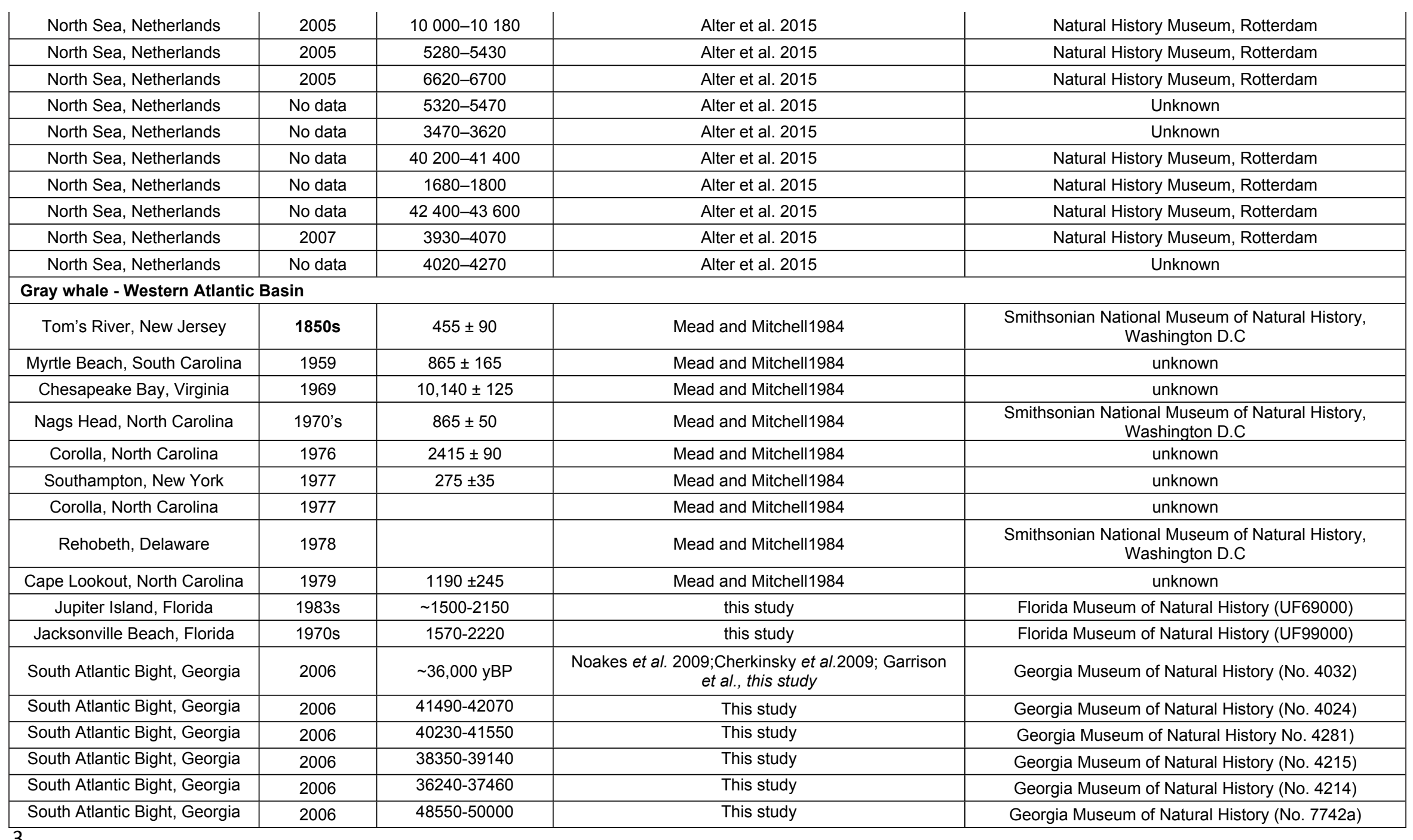

